\title{
ПОИСК ВЕЩЕСТВ, СНИЖАЮЩИХ ВНУТРИГЛАЗНОЕ ДАВЛЕНИЕ, СРЕДИ ИНГИБИТОРОВ GSКЗВ
}

\author{
Е.В. Соколова', В.Г. Клочков', Е.Н. Безсонова ${ }^{2}$, А.М. Ефремов²
}

${ }^{1}$ Кафедра фармакологии и биоинфоматики ФБОУ ВО Волгоградский государственный медицинский университет Минздрава России, 400131, Россия, г. Волгоград, площадь Павших Борцов, д. 1.

${ }^{2}$ Кафедра медицинской химии и тонкого органического синтеза химического факультета, ФГБОУ ВО МГУ, 119991, Москва, Ленинские горы, дом 1, строение 3, ГСП-1.

DOI: 10.19163/MedChemRussia2021-2021-347

E-mail: sokolova210795@gmail.com<smiles>[Y]C=C1C(=O)Nc2ccc([R])cc21</smiles>

Секретируемый родственный белок 1 (sFRP1) и киназа гликогенсинтазы $3 \beta$ (GSK3 $\beta$ ) снижают активность пути WNT/ $\beta$-catenin, приводя к нарушению оттока водянистой влаги глаза, что способствует повышению внутриглазного давления (ВГД) [1, 2]. Нами изучена активность новых производных 3-арилиден-2-оксиндола, синтезированных в МГУ имени М.В. Ломоносова [3] (см. таблицу).

\begin{tabular}{|c|c|c|c|c|c|c|c|c|}
\hline \multirow[b]{2}{*}{$\begin{array}{l}\text { № } \\
\text { п/ }\end{array}$} & \multirow[b]{2}{*}{$\mathbf{R}$} & \multirow[b]{2}{*}{$\mathrm{Ar}$} & \multicolumn{2}{|c|}{ GSK3 $\beta$} & \multicolumn{2}{|c|}{ \% снижения ВГД } & \multirow[b]{2}{*}{$\begin{array}{c}\text { Время } \\
\text { наступ- } \\
\text { ления тах } \\
\text { эффекта, ч }\end{array}$} & \multirow{2}{*}{$\begin{array}{c}\text { Выражен- } \\
\text { ность } \\
\text { резорб- } \\
\text { тивного } \\
\text { эффекта }\end{array}$} \\
\hline & & & $\begin{array}{c}\% \\
\text { ингибир. } \\
\text { при } 10 \\
\text { мкМ }\end{array}$ & $\mathrm{IC}_{50}$ & $\begin{array}{l}\text { опыт. } \\
\text { глаз }\end{array}$ & $\begin{array}{c}\text { контроль } \\
\text { глаз }\end{array}$ & & \\
\hline 1 & $\mathrm{H}$ & 2-пиридил & 95,7 & 0,0042 & 27,3 & 9,1 & 2,5 & + \\
\hline 2 & $\mathrm{MeOC}(\mathrm{O}) \mathrm{NH}$ & $4-\mathrm{OH}-\mathrm{Ph}$ & 91,82 & 0,1554 & 27,3 & 6,4 & 3 & + \\
\hline 3 & $\mathrm{NO}_{2}$ & $\sqrt{1}$ & 84,61 & 1.77 & 0 & 0 & - & \\
\hline 4 & $\mathrm{BzNH}$ & $4-\mathrm{OH}-\mathrm{Ph}$ & 58,94 & 4,343 & 18,2 & 9,1 & 2 & + \\
\hline 5 & $\mathrm{H}$ & & 49,2 & 5.68 & 0 & 0 & - & \\
\hline 6 & $\mathrm{H}$ & 4-MeO-Ph & 58,36 & 6.77 & 6.7 & 3 & 0.5 & \\
\hline 7 & $\mathrm{H}$ & & 39,88 & 10.03 & 0 & 0 & - & \\
\hline 8 & $\mathrm{MeC}(\mathrm{O}) \mathrm{NH}$ & $4-\mathrm{OH}-\mathrm{Ph}$ & 44,91 & 34.44 & 10 & 0 & 1 & \\
\hline \multicolumn{9}{|c|}{ Препараты сравнения } \\
\hline & SB-216763 & & 93,23 & 0,0084 & & & & \\
\hline & Тимолол & & & & 28,3 & 19,9 & 1 & +++ \\
\hline
\end{tabular}

Наибольшей ингибирующей активностью в отношении GSK3 $\beta$ обладали соединения

1 и 2 (IC 50,0042 и 0,1554 мкM). Производные пиразолов 3,5,7 не влияли на ВГД, а производное 2-пиридинкарбальдегида 1 показало выраженный гипотензивный эффект. Почти все производные с 4-гидроксифенильным фрагментом снижали ВГД, но лучший эффект показан для карбамоилпроизводного 8. 2-Оксиндолы 1 и 2 снижают ВГД на 27,3\% относительно исходного уровня и перспективны для разработки новых антиглаукомных средств.

Синтетическая часть работы выполнена при поддержке гранта РФФИ № 20-03-00915а.

\section{Литература}

[1] A. Vall, Y. Lecarpentier, J. Vall, Int. J. Mol. Sci, 2021, 22, 3780-3798.

[2] W. Wang, E.M. Stone, A.F. Clark, et al., A.F. Clark, J. Clin. Invest., 2008, 118(3), 1056-1064.

[3] N. A. Lozinskaya, D. A. Babkov, E.V. Zaryanova et al., Bioorg. Med. Chem, 2019, 27, 1804-1817. 